\title{
The Goal-Setting Features of Individuals with Myopia Diagnosis
}

\section{Особливості цілепокладання осіб із діагнозом міопія}

Lyudmyla Kolisnyk

Ph.D. in Psychology, Counselling Psychologist
Людмила Колісник

кандидат психологічних наук, практичний психолог

E-mail: Kolisnyk24lyu@gmail.com orcid.org/0000-0003-2872-1611

Sumy State University, Sumy, Ukraine

2, Rymskogo-Korsakova str., Sumy, Ukraine, 40007

Darya Freidlina 3rd-Year Student of the Department of Psychology, Political Sciences and Social Cultural Technologies
Сулський державний університет, ж. Сули, Украӥна вул. Римського-Корсакова, 2, м. Суми, Україна, 40007

Дар'я Фрейдліна студентка 3-го курсу кафедри психології, політології та соціокультурних технологій

E-mail:dfreidlina@gmail.com orcid.org/0000-0002-4560-1462

Sumy State University, Sumy, Ukraine

2, Rymskogo-Korsakova str., Sumy, Ukraine, 40007
Сулський державний університет, м. Сули, Україна вул. Римського-Корсакова, 2, м. Суми, Україна, 40007

Original manuscript received April 20, 2019 Revised manuscript accepted May 15, 2019

The author's contribution: L. Kolisnyk $-60 \%$, D. Freidlina-40\% . Авторський внесок: Л. Колісник- $60 \%$, Д. Фрейдліна- $40 \%$. 


\section{ABSTRACT}

The article is devoted to the analysis of the empirical study of the goal-setting peculiarities of the patients with myopia, which is one of the most widespread diagnoses in the world today. The authors carried out an analysis of works emphasizing the relationship between the state of a person's physical health and his/her psychological peculiarities. The work is based on the assumption that from the one hand, social factors play an important role in the formation of widespread visual impairments, from the other hand, visual impairment influences personality's features and as a consequence, his/her social behavior. The authors consider that character features of the patients with myopia are connected in particular with their goal-setting peculiarities.

To solve the set tasks, the following psychodiagnostic tools were used: A. Karmanov's questionnaire "Aim-Means-Result" and J. Buck's projective personality test "The house-tree-person test" (the main attention was paid to the interpretation of the position of the picture on the sheet). The reliability of the differences between the results of the selected respondents groups (control and experimental groups) was verified using the $t$-Student distribution.

The article reveals the features of the psychological portrait of people with myopia diagnosis. It has been proved that people with visual impairment have specific psychological characteristics, in particular, they differ in the specifics of goals setting and future planning. It has been found that such people are often characterized by uncertainty in the future, greater trust in past experience and small expectations for results. They have difficulties in goals setting, "vision" of the future, and are characterized by somewhat lower activity effectiveness compared with healthy respondents. It is more complicated for patients with myopia to set long-term goals.

Perspectives for further research are seen in the study of the influence of myopia diagnosis genesis features on the goals-setting specifics of such patients.

Key words: health, myopia, goals-setting, social factors, character.

\section{Вступ}

Сьогодні у світі однією з найпоширеніших хвороб вважають міопію, або короткозорість, яка є фактично вже епідемією XXI століття. У 2014 р. Всесвітня організація охорони здоров'я (ВООЗ) опублікувала статистику, згідно з якою близько 285 млн жителів планети страждають від порушень зору, з них 246 млн мають знижений зір. На короткозорість хворіє 35\% жителів Африки, 41\% населення 
США, 50\% європейців і понад 90\% азіатів. За прогнозами ВООЗ до 2050 року половина населення Землі носитиме окуляри (Савіна, 2017). Отже, проблема міопії у столітті технологій постала як ніколи гостро.

Із медичної точки зору на стан здоров'я очей негативно впливають генетична схильність, ненормоване проведення часу за комп'ютерами і смартфонами, погане освітлення приміщень, дефіцит сонячного світла тощо (Савіна, 2017). Проте зустрічаються випадки, коли шкідлива дія зовнішніх впливів відсутня, генетичний чинник не доведений, а людина має порушення зору. Пояснення такого феномену, на нашу думку, варто шукати у тісному зв'язку психічного стану та фізичного здоров'я людини. Доведено, що вплив психіки на фізичне здоров'я людини може бути набагато більшим за зовнішні чинники. Наприклад, якщо людина перебуває у постійному хвилюванні та напрузі, вона може скинути вагу, набути тремор тощо. Тож, можемо припустити існування взаємозв'язку між психологічними особливостями і зором людини.

Існує припущення, що особи, хворі на міопію, не бачать майбутнього та не можуть ставити перед собою довгострокові цілі. Вони фізично й абстрактно не бачать далечі. Але в науці бракує переконливих емпіричних досліджень, що підтверджують чи спростовують цю тезу.

Про взаємозв'язок властивостей характеру й особливостей здоров'я очей людини існує низка публікацій. Проте їх автори, не завжди висуваючи певні припущення, доводять свої твердження даними проведених ними наукових досліджень. Не зважаючи на це, маємо у літературі достатньо фактів залежності порушення зору від психологічних чинників, і навпаки (Малкіна-Пих, 2008; Сидоров, 2017; Фрейд, 2005; Фрейд, 1910; Norton, 2005).

Одним із перших науковців, який почав поглиблено вивчати взаємозв'язок фізичного та психологічного станів, був засновник психоаналізу Зигмунд Фрейд. Згідно з концепцією 3. Фрейда, у тих випадках, коли емоції ви- 
микаються з поля свідомості, тим самим втрачаючи адекватну розрядку, вони стають джерелом хронічної напруги і можуть породжувати істеричні симптоми. Енергія недозволеного емоційного конфлікту «перекладається» у тілесну сферу і викликає розвиток конверсійних симптомів, що виражають пригнічені, витіснені у несвідоме неприємні почуття. Однак викликана афектом енергетична напруга нікуди не зникає й обертається на хворобливий симптом. Витіснений емоційний (внутрішньо особистісний) конфлікт стає енергетичним резервуаром, який підживлює хворобу. Небажання прийняти вимоги суспільного життя або нездатність впоратися з труднощами змушує людей несвідомо шукати прихистку в хворобі. «Відхід у хворобу» $\epsilon$ компромісом, на який іде людина, намагаючись зберегти баланс між шкалами цінностей i небезпек. Хвороба при цьому стає способом адаптації, що дозволяє людині зберігати рівновагу у взаємодії зі світом (Фрейд, 2005).

У своїй статті «Психогенне порушення зору з позиції психоаналізу» 3. Фрейд розглядав взаємозв'язок зору та психологічних чинників (Фрейд, 1910). Він вважав, що істерична сліпота $є$ різновидом психогенного порушення зору. Його досліди показали, що істеричні сліпі у такому випадку бачать, хоча і не у повному сенсі. Збудження сліпого можуть мати відомі психічні наслідки, наприклад, викликати афекти, хоча вони і не усвідомлюються. Фрейд вважав, що істеричні сліпі - сліпі лише для свідомості, у несвідомому вони зрячі. Саме такий досвід змусив психоаналітика провести розмежування між свідомими і несвідомими психічними процесами.

Подальші досліди 3. Фрейда поясняють, що у схильних до істерії хворих із самого початку існує схильність до дисоціації - усунення взаємозв'язку з психічною подією, через що деякі несвідомі процеси не тривають у свідомому. Він залишив без уваги цінність пояснювальної спроби для розуміння розглянутих явищ і звернувся до іншої точки зору. 3. Фрейд підкреслив тотожність істеричної сліпоти зі 
сліпотою, викликаною навіюванням. Істеричні хворі - сліпі не внаслідок викликаного собі уявлення, що вони не бачать, а внаслідок дисоціації між несвідомими і свідомими процесами в зоровому акті; їх уявлення про те, що вони не бачать, є правомірним вираженням психічного стану речей, а не його причиною (Фрейд, 1910).

Вплив стресів на діяльність внутрішніх органів, зокрема, на імунні процеси, підтверджено даними численних клінічних і експериментальних досліджень. Однак, травмуючі події - лише одна зі складових патогенезу психосоматичних розладів. Значна роль у формуванні психосоматичних захворювань належить особистісним властивостям (Пацирова, 2010).

Вільгельм Райх, австрійський і американський психолог-неофрейдист, виокремлював сім сегментів тіла, які у разі виникнення у них відповідних "м'язових затискачів» блокують природний рух «вегетативної енергії», перетворюючись у кільця «м'язового панцира». Це такі сегменти, як очі, рот, шия, груди, діафрагма, живіт, таз (Сандомирський, 2005). Так, у випадку очей (включаючи мімічні м'язи навколо очей і лобовий м'яз) блокується багато емоціï, пов’язаних зі стресом ( ппорожні очі», «мертвий лоб»), відображаючи загальний стан напруженості, бажання відгородитися від навколишнього світу, «не бачити», не помічати проблем. Тут також часто локалізуються головні болі, пов'язані з тривалою перевтомою, астенізацією нервової системи ( шшолом неврастеніка»). Нерідко це інтелектуальне перевантаження, викликане надмірністю інформаційного потоку - інформаційний стрес.

В. Оклендер, узагальнюючи досвід своєї психотерапевтичної роботи у гештальт-підході, однією з перешкод на шляху здатності бачити вважає схильність передбачити майбутнє замість того, щоб бачити сьогодення (Дорошева, 2014).

П. Вацлавік, представник школи системної психотерапії, розглядає порушення зору в контексті соціалізації. Він 
описує їх як спробу обмежити комунікацію (наприклад, iз метою зниження впливу іншої людини - не зважати на їі повідомлення або приховати власну реакцію) або знехтувати частиною інформації, щоб уникнути протиріч при прийнятті рішень (у парадигмі перцептивних захистів). Порушення зору, за П. Вацлавіком, є неспецифічними для вирішення цього завдання, стаючи у ряд із такими проявами, як розлади уваги або шизофренія. Вибір конкретного способу реагування на комунікативні порушення у середовищі, що вимагають включення захисних механізмів, він вважає обумовленим спадковими схильностями, індивідуальним досвідом (Сандомирський, 2005).

Отже, можна припускати, що соціальні чинники можуть відігравати значну роль у формуванні «масових» порушень зору, які можна розглядати, з одного боку, як безпосередню форму адаптації (можливо, дають змогу здійснювати несуперечливу селекцію інформації, пов'язану із соціальними взаємодіями), а 3 іншого боку - як наслідок фізіологічних змін, пов'язаних з іншими стратегіями адаптації у соціумі (наприклад, наполеглива робота над складними завданнями, які ставлять інші люди, що призводить до перенапруги і зменшення або виключення часу для релаксації).

3 особливостями стратегії поведінки людини у соціумі пов' язаний механізм її цілепокладання. Жћиттєве цілепокладання - це складне динамічне утворення, що перебуває у стані постійного оновлення під дією все нових смислів. Воно є найбільш усвідомленою і суб'єктною формою структурування майбутнього, найдієвішим механізмом самореалізації. Постановка життєвих цілей обумовлюється комплексом соціально-психологічних чинників, серед яких i чинник саморозвитку, самоактуалізації (Манукян, 2018).

Ефективне життєве цілепокладання визначається високим рівнем усвідомлення цілей, розгорнутістю у простоpi, яка втілюється у кількості задіяних сфер, поєднанням 
глобальної, віддаленої і короткочасної часових перспектив, узгодженістю, логічністю та реалістичністю цілей, позитивним ставленням до майбутнього, достатнім усвідомленням чинників, що впливають на постановку життєвих цілей, а також їх переважно інтернальною спрямованістю й активною, дієвою життєвою позицією.

Механізм цілепокладання - основний елемент процесу прийняття рішень. Згідно первинної моделі процесу постановки цілей, людина усвідомлює й оцінює події, що відбуваються в їі оточенні, з урахуванням емоційної реакції. На грунті такої оцінки визначаються цілі та реалізуються певні дії для їх досягнення, отримується результат і задоволення від нього. Діяльність суб'єкта, який не здатен самостійно ставити цілі, спрямовується лише зовні. У процесі самостійних дій діяльність такого суб'єкта має випадковий характер, наслідки їі можуть бути негативними - від втрати ресурсів до втрати сенсу життя (Воронов, 2017).

На основі вивчення літератури та пілотного спостереження ми припускаємо, що особи з порушенням зору мають специфічні психологічні особливості, зокрема, вирізняються специфікою постановки цілей і планування майбутнього. Через свою хворобу вони не можуть бачити не лише фізично. Таким людям складно ставити перед собою цілі та досягати їх. Вони не бачать чітко свого майбутнього і не можуть реалізувати себе. 3 метою перевірки сформульованого припущення нами було проведено дослідження.

Мета статті - висвітлити особливості психологічного портрета, а саме специфіки цілепокладання, осіб із діагнозом міопія.

\section{Завдання статті}

1. Розкрити характер зв'язку фізіологічних і психологічних особливостей особистості.

2. Описати специфіку цілепокладання осіб із діагнозом міопія; порівняти результати з контрольною групою досліджуваних (особи, що не мають порушень зору). 


\section{Методи та методики дослідження}

Для вивчення особливостей цілепокладання осіб із діагнозом міопія нами було використано теоретичні (теоретико-методологічний аналіз, класифікація та систематизація наукових джерел, порівняння й узагальнення даних теоретичних і експериментальних досліджень) та емпіричні (анкетування, психологічне тестування) методи дослідження, а також методи обробки даних (узагальнення та систематизація якісних і кількісних даних емпіричного дослідження; методи математичної статистики).

3'ясування особливостей структури діяльності та вміння визначати мету відбувалося за допомогою методики «Мета-Засіб-Результат» А. А. Карманова. Основні риси будь-якої діяльності розглядаються через три компоненти: 1) на початку будь-якої діяльності людина, синтезуючи велику кількість інформації, ставить мету діяльності, тобто починає представляти більш або менш ясну картину бажаного майбутнього, той кінцевий стан, який особа хоче бачити; 2) обирається ресурс, який людина готова витратити на досягнення мети; 3) актуалізація результату як підсумок будь-якої діяльності.

Також для дослідження особливостей цілепокладання та відчуття себе у часі була використана одна з найвідоміших проективних методик дослідження особистості «Будинок-Дерево-Людина» Дж. Бука. Кожен малюнок це своєрідний автопортрет, деталі якого мають особистісне значення (Лебедева, Никонорова \& Тараканова, 2010). Інтерпретація малюнків досліджуваних відбувалася 3 урахуванням закономірностей, описаних автором i його колегами. Основну увагу було приділено інтерпретації положення малюнка на аркуші. Для зручності аналізу було виокремлено сім позицій малюнка на аркуші: рівномірний розподіл (зображення займає фактично весь аркуш); орієнтація на минуле (зображення зосереджене на лівій стороні аркуша); орієнтація на майбутнє (зображення зосередже- 
не на правій стороні аркуша); сфера фантазій (зображення зосереджене переважно у верхній частині аркуша); заземлення у реальності (зображення зосереджене переважно у нижній частині аркуша); брак орієнтацій на майбутнє (зображення зосереджене переважно на лівій стороні аркуша); брак минулого досвіду (зображення зосереджене переважно на правій стороні аркуша).

Дослідницько-експериментальна робота переважно виконувалася на базі Сумського державного університету. В дослідженні брали участь студенти першого та другого курсу спеціальності «Психологія», а також інші молоді люди у віці від 18 до 20 років загальною кількістю 37 осіб. Із них 17 - особи, хворі на міопію (експериментальна група), 20 - молодь без офтальмологічних діагнозів (контрольна група). Під час діагностики стан досліджуваних був спокійним, молоді люди були мотивовані на роботу.

\section{Результати та дискусії}

Аналіз отриманих даних за методикою «Мета-Засіб-Результат» А. А. Карманова виявив, що середні значення показників здорових і хворих респондентів за всіма шкалами мають лише невеликі відмінності (табл. 1).

Таблиия 1

Особливості цілепокладання здорових та осіб із діагнозом міопія (за методикою «Мета-Засіб-Результат» А. А. Карманова)

\begin{tabular}{|l|c|c|c|c|c|c|}
\hline & \multicolumn{3}{|c|}{ Короткозорі } & \multicolumn{3}{c|}{ Здорові } \\
\cline { 2 - 7 } & Мета & Засіб & $\begin{array}{c}\text { Резуль- } \\
\text { тат }\end{array}$ & Мета & Засіб & $\begin{array}{c}\text { Резуль- } \\
\text { тат }\end{array}$ \\
\hline Середнє & 9,17947 & 9,88235 & 6,23529 & 8,95 & 10,10 & 7,40 \\
\hline Дисперсія & 4,26298 & 5,86851 & 11,23880 & 6,60 & 10,99 & 12,04 \\
\hline $\begin{array}{l}\text { Стандартне } \\
\text { відхилення }\end{array}$ & 2,12824 & 2,49706 & 3,45560 & 2,635786 & 3,401238 & 3,560012 \\
\hline $\begin{array}{l}\text { Коефіцієнт } \\
\text { варіації }\end{array}$ & 23,18000 & 25,2700 & 55,42000 & 29,45 & 33,68 & 48,11 \\
\hline
\end{tabular}


Помітно, що в обох групах досліджуваних найвищі показники за шкалою «Засіб». Це означає, що спочатку респонденти починають діяти, а лише потім замислюються над метою своєї діяльності. За шкалою «Результат» спостерігаються відмінності практично на 2 пункти. Це може вказувати на те, що здорові люди «бачать» свій результат ще на початку діяльності. Також, можливо, це свідчить про те, що здорові респонденти більше націлені на досягнення своєї мети, ніж респонденти з хворобою. Поясненням може бути й те, що здорова людина впевненіша в собі та своїх силах, оскільки має позитивний фізичний стан, що додає їй психологічної впевненості. На противагу цьому, хворобливий стан завжди має негативний вплив на людину, який у випадку хронічної хвороби ще більш значний. Людина може зневіритися у своїх силах, проявляти низьку активність, сподіваючись на піклування про неї інших.

Достовірність відмінностей між результатами виокремлених груп досліджуваних було перевірено за допомогою t-критерію Стьюдента (табл. 2).

Таблиия 2

Значущість відмінностей між отриманими результатами здорових та осіб із міопією

(за методикою А. А. Карманова «Мета-Засіб-Результат»)

\begin{tabular}{|c|c|c|c|c|c|}
\hline \multicolumn{5}{|c|}{ Значущість відмінностей } \\
\hline \multicolumn{2}{|c|}{ Мета } & \multicolumn{2}{|c|}{ Засіб } & \multicolumn{2}{c|}{ Результат } \\
\hline Короткозорі & Здорові & Короткозорі & Здорові & Короткозорі & Здорові \\
\hline $\mathrm{p} \leq 0,05$ & $\mathrm{p} \leq 0,01$ & $\mathrm{p} \leq \mathbf{0 , 0 5}$ & $\mathrm{p} \leq \mathbf{0 , 0 1}$ & $\mathrm{p} \leq \mathbf{0 , 0 5}$ & $\mathrm{p} \leq \mathbf{0 , 0 1}$ \\
\hline 2,03 & 2,72 & 2,03 & 2,72 & 2,03 & 2,72 \\
\hline tемп $=0,3$ & \multicolumn{2}{|c|}{ tемп $=0,2$} & \multicolumn{2}{c|}{ tемп $=1$} \\
\hline У зоні значущості & У зоні значущості & \multicolumn{2}{c|}{ У зоні значущості } \\
\hline
\end{tabular}

Отримані дані показують, що всі результати знаходяться у зоні значущості. Це свідчить про різні психологічні особливості респондентів обох груп. Ці особливості стосуються структури діяльності та конкретно цілепокладання. 


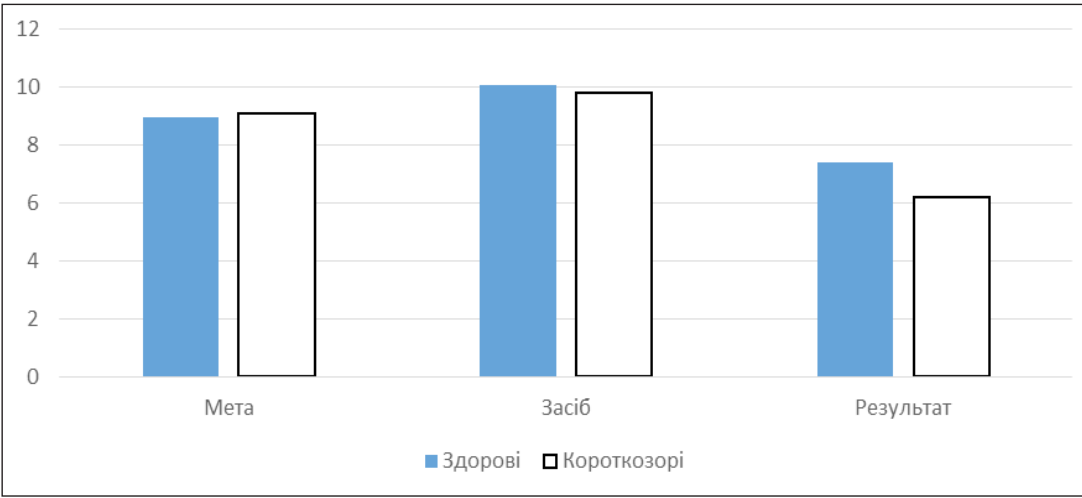

Puc. 1. Середні значення показників здорових та осіб із діагнозом міопія (за методикою А. А. Карманова «Мета-Засіб-Результат»)

Для інтерпретації результатів методики «БудинокДерево-Людина» всі малюнки було згруповано відповідно до особливостей їх розташування на аркуші. Для зручності інтерпретації нами виокремлено сім позицій малюнка, вказаних у табл. 3. Інтерпретація була здійснена на основі описаних Дж. Буком особистісних особливостей (Лебедева, Никонорова \& Тараканова, 2010).

Таблиия 3

Показники розподілу позицій малюнка, \% (за методикою Дж. Бука «Будинок-Дерево-Людина»)

\begin{tabular}{|l|c|c|}
\hline \multicolumn{1}{|c|}{ Позиції } & Здорові & Короткозорі \\
\hline Рівномірний розподіл & 25 & 19 \\
\hline Орієнтація на минуле & 0 & 7 \\
\hline Орієнтація на майбутнє & 11 & 0 \\
\hline Сфера фантазій & 19 & 11 \\
\hline Заземлення в реальності & 8 & 22 \\
\hline Брак орієнтацій на майбутнє & 22 & 22 \\
\hline Брак минулого досвіду & 14 & 11 \\
\hline
\end{tabular}


Отримані результати свідчать, що більше впевненості у собі та гармонії у власному житті мають здорові респонденти. Також здорові досліджувані мають більше орієнтацій на майбутнє (11\% здорових досліджуваних порівняно з 0\% хворих) і високий, порівняно з короткозорими особами, відхід у сферу фантазій (здорові - 19\%, короткозорі $11 \%$ ). Це може вказувати на те, що здорові люди живуть майбутнім і мріють про нього. Ознака «Орієнтація на минуле» у здорових відсутня взагалі - жоден досліджуваний не відзначив це у своїй роботі. Можливо, це свідчить, що здорові особи живуть майбутнім.

У респондентів із короткозорістю протилежні результати. У таких осіб відсутня ознака «Орієнтація на майбутнє» $(0 \%)$. Це може свідчити про відсутність цілей і планів на майбутнє. Респонденти з міопією, можливо, надають перевагу теперішнім і минулим подіям. Але результати за ознакою «Орієнтація на минуле» невисокі. Її демонструє лише 7\% досліджуваних із короткозорістю. Отримані дані за ознакою «Заземлення у реальність» набагато перевищують результат здорових (здорові - 8\%, короткозорі - 22\% ). Це може означати, що особи з короткозорістю живуть, переважно, у теперішньому, але дещо дивляться у минуле. Тому ознака «Брак минулого досвіду» в короткозорих респондентів менш виражена, ніж у здорових (здорові - 14\%, короткозорі - 11\%).

Результати за ознакою «Брак орієнтацій на майбутнє» виявилися однаково високими як у здорових досліджуваних, так і в осіб із міопією $(22 \%)$, що може бути пов'язано з віком опитуваних. Молодим людям властиво ставити перед собою абстрактні та недосяжні цілі.

За загальними результатами методики «Будинок-Дерево-Людина» можна стверджувати, що така риса характеру, як цілепокладання, більш розвинута у здорової групи опитуваних. Здорові респонденти частіше дивляться у майбутнє, мріють і ставлять цілі. Серед хворих на міопію 
багато тих, хто надто заземлений у теперішній реальності й, навіть, може тяжіти до минулого.

Як бачимо, результати, отримані за двома методиками, дещо різняться. Так, за методикою А. А. Карманова «Мета-Засіб-Результат» відмінності між досліджуваними групами не є різко вираженими. На відміну від даних опитувальника, результати методики Дж. Бука «Будинок-Дерево-Людина» демонструють чіткі тенденції у вираженні особистісних особливостей груп досліджуваних. На нашу думку, це пов'язано зі специфікою запропонованого діагностичного інструментарію. Застосування проективної методики надає змогу проведення глибшого дослідження. По-перше, у такому випадку можливо з'ясувати не лише особливості, усвідомлені досліджуваними, а й ті, які ними не відрефлексовані. По-друге, використання проективного методу мінімізує можливість досліджуваного надавати про себе інформацію у соціально привабливій формі. Поясненням виявленої тенденції може бути те, що у зв'язку з появою діагнозу міопія відбувається певна зміна життєдіяльності таких хворих, і це позначається на їх психологічних особливостях. Проте, цілком можливо, що саме психологічні особливості, визначаючи життєвий стиль особистості, сприяють виникненню специфічних зорових розладів.

Отже, результати проведеного емпіричного дослідження певною мірою підтверджують факт наявності взаємозв'язку між порушенням зору та психологічними особливостями особистості, описаним у роботах низки вчених (Малкина-Пых, 2008; Пацырова, 2010; Сидоров, 2017; Фрейд, 2005; Фрейд, 1910; Norton, 2005). Проте виявлені нами особливості цілепокладання осіб із діагнозом міопія суперечать, наприклад, даним В. Оклендера, який стверджує, що однією з перешкод на шляху здатності бачити $є$ схильність передбачити майбутнє замість того, щоб бачити сьогодення (Дорошева, 2014). Тож, питання потребує подальшого вивчення. 


\section{Висновки}

За результатами проведеного дослідження виявлено особливості цілепокладання осіб із діагнозом міопія, зокрема у постановці цілей і плануванні майбутнього. Констатовано, що людям із діагнозом міопія характерна невпевненість у майбутньому, більша довіра до досвіду минулого та невеликі сподівання на результат. Вони мають труднощі з постановкою цілей, «баченням» майбутнього, характеризуються дещо нижчою результативністю діяльності порівняно зі здоровими респондентами. Хворим на міопію складніше ставити перед собою довгострокові цілі.

Перспективи подальших досліджень вбачаються нами у продовженні вивчення окресленої проблеми із застосуванням додаткового психодіагностичного інструментарію, а також у з'ясуванні впливу особливостей ґенези діагнозу міопія на специфіку цілепокладання таких хворих.

\section{Література}

Волженцева I. В. Дослідження самопочуття, активності та настрою студентів із міопією в умовах психофізичної корекції. Aktualne problemy verejnej spravy: Jnovatne vyskum v oblasti sociologie, psychologie a politologie (10-11 marca). 2017. C. 61-65.

Воронов О. Цілепокладання в управлінській сфері. Державне управління. 2017. № 1 (57). С. 34-35, 37.

Гулий Ю., Научитель О., Долгополова О. Особливості взаємозв'язку самооцінки і поведінкової складової «Я-концепції» особистості з аномалією рефракції (на прикладі короткозорості). Психологічне консультування і психотерапія. 2018. № 9. С. 63-69.

Дорошева Е. А. Эволюционный подход к вопросам формирования близорукости: перестройка зрительного анализатора как адаптация к социокультурным условиям. Эксперилентальная психология. 2014. Том 7. № 3. С. 83-96.

Лебедева Л. Д., Никонорова Ю. В., Тараканова Н. А. Энциклопедия признаков и интерпретаций в проективном рисовании и арт-терапии. Санкт-Петербург : Речь, 2010. 336 с.

Малкина-Пых И. Г. Психосоматика. Москва : Эксмо, 2008. 1230 с.

Манукян В. Р. Опыт исследования индивидуально-психологических особенностей целеполагания и жизненного планирования. Психологические исследования. 2018. Т. 11. № 57. С. 9. 
Пацырова Л. А., Мельник Е. В., Латюшин Я. В. Психологические предпосылки психосоматических заболеваний у работников образования. Научно-теоретический журнал. 2010. Вып. 1 (3). С. 53-54.

Райгородский Д. Я. Энциклопедия психодиагностики. Психодиагностика взрослых. Самара : Бахрах-М, 2009. 704 с.

Рева М. Специфіка життєвого цілепокладання молоді у контексті прагнення до самореалізації. Наука і освіта. 2015. № 10. С. 107.

Савіна О. М. Клініко-епідеміологічне обгрунтування заходів ранньої діагностики, лікування та профілактики вродженої і спадкової патології органу зору в дітей в Україні: автореф. дис. ... канд. мед. наук: 14.01.18. Київ, 2017. 23 с.

Сандомирский М. Е. Психосоматика и телесная психотерапия. Москва : Класс, 2005. 592с.

Сидоров И. Ю., Решетова П. С., Соболева Е. В. Психосоматический аспект патологии рефракции. Вестник совета молодых ученых $u$ специалистов Челябинской области. 2017. Вып. 4 (19). С. 99-100.

Субботіна Г. С. Результати дослідження особистісного розвитку хворих на міопію підлітків після танцювально-рухової терапії. Збірник наукових праць Кал'янець-Подільського національного університету ілені I. Огієнка, Інституту психологї ілені Г. С. Костюка НАПН Украӥни. Кам'янець-Подільський : Аксіома, 2014. Вип. 25. С. 468-483.

Фрейд 3. Исследование истерии. Собрание сочинений в 26 томах. Т. 1. Восточно-Европейский Институт Психоанализа, 2005. 466 с.

Фрейд 3. Психогенное нарушение зрения с позиции психоанализа. Собрание сочинений в 10 томах. Том 6. Истерия и страх. 1910. 205 с.

Edwards, M. H., \& Lam, C. S. Y. (2004). The epidemiology of myopia in Hong Kong. Annals academy of medicine Singapore, 33 (1), 34-38.

Norton, T. T., Manny, R., \& O’Leary, D. J. (2005). Myopia-Global Problem, Global Research. Optometry \& Vision Science, 82, 4, 223-225.

\section{References}

Volzhentseva, I. V. (2017). Doslidzhennia samopochuttia, aktyvnosti ta nastroiu studentiv iz miopiieiu v umovakh psykhofizychnoi korektsii [Investigation of the state of health, activity and mood of students with myopia in conditions of psychophysical correction]. Aktualne problemy verejnej spravy: Jnovatne vyskum v oblasti sociologie, psychologie a politologie, (pp. 61-65) [in Ukrainian].

Voronov, O. (2017). Tsilepokladannia v upravlinskii sferi [Goal setting in the managerial field]. Derzhavne upravlinnia - Public administration, 1 (57), 34-35, 37 [in Ukrainian].

Gulyi, Yu., Nauchytel, O., \& Dolgopolova, O. (2018). Osoblyvosti vzaiemozviazku samootsinky i povedinkovoi skladovoi «Ya-kontseptsii»

(C) Lyudmyla Kolisnyk, Darya Freidlina 
osobystosti $\mathrm{z}$ anomaliieiu refraktsii (na prykladi korotkozorosti) [Features of the relationship between self-esteem and the behavioral component of the "Me-concept» of the personality with refractive anomaly (on the example of myopia)]. Psykholohichne konsultuvannia i psykhoterapiia - Psychological counseling and psychotherapy, 9 , 63-69 [in Ukrainian].

Dorosheva, E. A. (2014). Jevoljutsionnyj podhod k voprosam formirovanija blizorukosti: perestrojka zritel'nogo analizatora kak adaptatsija $\mathrm{k}$ sotsiokul'turnym uslovijam [Evolutionary approach to the problems of the formation of myopia: adjustment of the visual analyser as an adaptation to socio-cultural conditions]. Jeksperimental'naja psihologija - Experimental psychology, 7, 3, 83-96 [in Russian].

Lebedeva, L. D., Nikonorova, Ju. V., \& Tarakanova, N. A. (2006). Jentsiklopedija priznakov $i$ interpretatsij $v$ proektivnom risovanii $i$ art-terapii [Encyclopedia of signs and interpretations in projective drawing and art therapy]. Sankt-Peterburg : Rech' [in Russian].

Malkina-Pyh, I. G. (2008). Psihosomatika [Psychosomatics]. Moskva : Jeksmo [in Russian].

Manukjan, V. R. (2018). Opyt issledovanija individual'no-psihologicheskih osobennostej tselepolaganija i zhiznennogo planirovanija [Experience in the study of individual psychological characteristics of goal setting and life planning]. Psihologicheskie issledovanija - Psychological research, 11, 57, 9 [in Russian].

Patsyrova, L. A., Mel'nik, E. V., \& Latjushin, Ja. V. (2010). Psihologicheskie predposylki psihosomaticheskih zabolevanij u rabotnikov obrazovanija [Psychological causes of psychosomatic diseases of education workers]. Nauchno-teoreticheskij zhurnal - Scientific and theoretical journal, 1 (3), 53-54 [in Russian].

Rajgorodskij, D. Ja. (2009). Jentsiklopedija psihodiagnostiki. Psihodiagnostika vzroslyh [Encyclopedia of psychodiagnostics. Adult Psychodiagnosis ]. Samara : Bahrah-M [in Russian].

Reva, M. (2015). Spetsyfika zhyttievoho tsilepokladannia molodi u konteksti prahnennia do samorealizatsii [The specificity of the goal of life for young people in the context of the desire to self-fulfillment]. Nauka i osvita - Science and education, 10, 107 [in Ukrainian].

Savina, O. M. (2017). Kliniko-epidemiolohichne obgruntuvannia zakhodiv rannoi diahnostyky, likuvannia ta profilaktyky vrodzhenoi i spadkovoi patolohii orhanu zoru u ditei v Ukraini [Clinical and epidemiological substantiation of early diagnostics, treatment and prevention of congenital and hereditary pathology of the body of vision in children in Ukraine]. Extended abstract of Doctor's thesis. Kyiv [in Ukrainian]. 
Sandomirskij, M. E. (2005). Psihosomatika i telesnaja psihoterapija [Psychosomatics and corporal psychotherapy]. Moskva : Klass [in Russian].

Sidorov, I. Ju., Reshetova, P. S., \& Soboleva, E. V. (2017). Psihosomaticheskij aspekt patologii refraktsii [Psychosomatic Aspect of Refraction Pathology]. Vestnik soveta molodyh uchenyh $i$ spetsialistov Cheljabinskoj oblasti-Bulletin of the council of young scientists and specialists of the Cheliabinsk region, 4 (19), 99-100 [in Russian].

Subbotina, H. S. (2014). Rezultaty doslidzhennia osobystisnoho rozvytku khvorykh na miopiiu pidlitkiv pislia tantsiuvalno-rukhovoi terapii [Results of the study of the personal development of teens with myopia after dance-motor therapy]. Problemy suchasnoi psykholohii - Problems of Modern Psychology: Collection of research papers of Kamianets-Podilskyi National Ivan Ohiienko University, G. S. Kostiuk Institute of Psychology of the National Academy of Educational Sciences of Ukraine, 25, 468-483. Kamianets-Podilskyi : Aksioma [in Ukrainian].

Freud, Z. (2005). Issledovanie isterii. Sobranie sochinenij v 26 tomah [Hysteria research. Collected works in 26 volumes]. Sankt-Peterburg : Vostochno-Evropejskij Institut Psihoanaliza [in Russian].

Freud, Z. (1910). Psihogennoe narushenie zrenija s pozitsii psihoanaliza [Psychogenic vision impairment from the perspective of psychoanalysis ]. (Vols. 1-10). Sankt-Peterburg [in Russian].

Edwards, M. H., \& Lam, C. S. Y. (2004). The epidemiology of myopia in Hong Kong. Annals academy of medicine Singapore, 33 (1), 34-38.

Norton, T. T., Manny, R., \& O’Leary, D. J. (2005). Myopia-Global Problem, Global Research. Optometry \& Vision Science, 82, 4, 223-225.

\section{Колісник Людмила, Фрейдліна Дар'я. Особливості цілепокладання осіб із діагнозом міопія}

\section{АНОТАЦІЯ}

Статтю присвячено аналізу емпіричного вивчення особливостей цілепокладання хворих із діагнозом міопія, який сьогодні у світі є одним із найпоширеніших. Авторами здійснено аналіз робіт, які підкреслюють взаємозв'язок між станом фізичного здоров'я людини та їі психологічними особливостями. Робота базується на припущенні, що, з одного боку, соціальні чинники відіграють важливу роль у формуванні поширених порушень зору, з іншого боку, порушення зору впливає на особливості особистості та, як наслідок, на їі соціальну поведінку. Автори вважають, що характерні риси хворих на короткозорість пов'язані, зокрема, з особливостями постановки ними цілей. 
Для вирішення поставлених завдань використовувалися такі психодіагностичні методики: анкета А. А. Карманова «Мета-ЗасібРезультат» і проекційний тест особистості Дж. Бука «Будинок-Дерево-людина» (основна увага приділялася інтерпретації положення зображення на аркуші). Достовірність відмінностей між результатами відібраних груп респондентів (контрольної та експериментальної) перевірялася за допомогою t-критерію Стьюдента.

У статті розкрито особливості психологічного портрета людей із діагнозом короткозорості. Доведено, що особи з порушенням зору мають специфічні психологічні особливості, зокрема, вирізняються специфікою постановки цілей і планування майбутнього. Виявлено, що такі люди часто характеризуються невпевненістю у майбутньому, більшою довірою до досвіду минулого та невеликими сподіваннями на результат. Вони мають труднощі з постановкою цілей, “баченням» майбутнього, характеризуються дещо нижчою результативністю діяльності порівняно зі здоровими респондентами. Хворим на міопію складніше ставити перед собою довгострокові цілі.

Перспективи подальших досліджень вбачаються у вивченні впливу особливостей ґенези діагнозу міопія на специфіку цілепокладання хворих із таким діагнозом.

Ключові слова: здоров'я, міопія, цілепокладання, соціальні чинники, характер.

Колиснык Людмила, Фрейдлина Дарья. Особенности целеполагания людей с диагнозом миопия

\section{АННОТАЦИЯ}

Статья посвящена изучению особенностей целеполагания больных с диагнозом миопия, который сегодня в мире является одним из самых распространенных. Авторами проведен анализ работ, которые подчеркивают взаимосвязь между состоянием физического здоровья человека и его психологическими особенностями. Работа базируется на предположении, что, с одной стороны, социальные факторы играют важную роль в формировании распространенных нарушений зрения, с другой стороны, нарушение зрения влияет на особенности личности и, как следствие, на её социальное поведение. Авторы считают, что характерные черты больных близорукостью связаны, в частности, с особенностями постановки ими целей. 
Для решения поставленных задач использовались такие психодиагностические методики: анкета А. А. Карманова «Цель-СредствоРезультат» и проективный тест личности Дж. Бука "Дом-ДеревоЧеловек» (основное внимание уделялось интерпретации положения изображения на листе). Достоверность различий между результатами отобранных групп респондентов (контрольной и экспериментальной) проверялась с помощью t-критерия Стьюдента.

В статье раскрыты особенности психологического портрета людей с диагнозом близорукости. Доказано, что лица с нарушением зрения имеют специфические психологические особенности, в частности, отличаются спецификой постановки целей и планирования будущего. Выявлено, что такие люди часто характеризуются неопределенностью в будущем, большей уверенностью в опыте прошлого и небольшими надеждами на результат. Они испытывают трудности с постановкой целей, «видением» будущего, характеризуются более низкой результативностью деятельности по сравнению со здоровыми респондентами. Больным миопией сложнее ставить перед собой долгосрочные цели.

Перспективы дальнейших исследований авторы видят в изучении влияния особенностей генезиса диагноза миопия на специфику целеполагания больных с таким диагнозом.

Ключевые слова: здоровье, миопия, целеполагание, социальные факторы, характер. 